\title{
How Critical Thinking is Taught in Qatari Independent Schools' Social Studies Classrooms: Teachers' Perspectives
}

\author{
Michael H. Romanowski (Corresponding author) \\ Educational Sciences Department, Qatar University \\ PO Box 2713, Doha, Qatar
}

Tel: 974-485-5142Ｅ-mail: michaelhr@qu.edu.qa

\author{
Ramzi Nasser \\ School of Economics, Nevada State University \\ Educational Sciences Department, Qatar University \\ PO Box 2713, Doha, Qatar \\ Tel: 974-485-5144 E-mail: ramzin@qu.edu.qa
}

Received: January 18, 2012 Accepted: February 6, 2012 Published: March 11, 2012

doi:10.5296/ije.v4i1.1304 URL: http://dx.doi.org/10.5296/ije.v4i1.1304

\begin{abstract}
Qatar is in the midst of a massive systemic education reform Education For a New Era. A key aspect of the reform is the expectation of teachers to develop students' critical thinking skills. In this paper, an open-ended questionnaire and follow-up interviews revealed several aspects of critical thinking including how it is defined and taught, where in the curriculum does critical thinking flourish, and challenges and limitations of the teaching of critical thinking from the perspectives of social studies teachers in preparatory and secondary Qatari independent schools.
\end{abstract}

Keywords: Critical thinking, Social studies education, International education 


\section{Introduction}

In 2001, the Qatari government became alarmed that the country's educational system was "not producing high-quality outcomes" probably as benchmarked by international league tables (for example, Trends in International Mathematics and Science Study (TIMMS) and the Programme for International Student Assessment (PISA)) (Brewer, et al., 2007, p. iii). In response, the Qatari government approached RAND, a nonprofit research organization and requested a comprehensive examination of Qatar's K-12 education system. RAND was given the task of investigating the existing educational system providing recommendations and options for building "a world-class system that would meet the country's changing needs" (Brewer, et. al. 2007, p. xvii).

Upon the completion of their analysis, the RAND put forward three options. These are as follows:

(1) a Modified Centralized Model, which upgraded the existing, centrally controlled system by adding or improving the basic elements; (2) a Charter School Model, which decentralized governance and encouraged variety through a set of schools independent of the Ministry and which allowed parents to choose whether to send their children to these schools; and (3) a Voucher Model, which offered parents school vouchers so that they could send their children to private schools and which sought to expand high-quality private schooling in Qatar (Rand, 2007, p. xxi).

In that same year, 2001, Qatar introduced a comprehensive national education reform policy Education For a New Era (EFNE) that consisted the development of government funded independent schools operated by individuals who are under contract from the Supreme Education Council (SEC). The first twelve government-funded Independent Schools opened in 2004 with the goal of turning Qatar's vision of developing a world-class education system into a reality.

The Qatar government elected to support a charter school model that decentralizes education and encourages the development of independent schools. The model is based on the four principles of 1) autonomy for schools, 2) accountability through a comprehensive assessment system, 3) variety in schooling alternatives, and 4) choice for parents, teachers, and school operators. In response, Qatari officials have developed a two-pronged approach to reform: (1) the establishment of government-funded Independent Schools over a period of some years and (2) the implementation of annual assessments to measure student learning and school performance (SEC, 2009). The first twelve government-funded Independent Schools opened in 2004 with the goal of turning Qatar's vision of developing a world-class education system into a reality. Currently there are 167 independent schools in Qatar.

EFNE has drastically changed the educational landscape in Qatar by creating a supply of high quality schools that build human capacity through training, integration of educational policies with wider social policies, continuous change and innovative pedagogical methods that promote inquiry, discovery and critical approaches (Brewer, et al., 2006). Furthermore, EFNE 
has an interest in providing qualified employees to the Qatari workforce that requires the development of particular skills such as critical thinking, communication, and teamwork skills (Stasz, Eide, \& Martorell, 2007). For the purpose of this paper, we limit our examination of EFNE to one of the pillars of the reform, namely critical thinking in the curriculum and the development of critical thinking in students particularly in the social studies classroom.

Highlighted in Rand's analysis and most relevant to our discussion is the current Qatari educational system and "unchallenging" curriculum that "emphasized rote memorization" (Brewer, et. al., 2007, p. xviii). Because of this criticism, EFNE goals were to promote teachers to promote critical thinking skills by providing opportunities for students" (Brewer, et. al., 2007, p. 103) to be able to critically question and reflect. Critical thinking skills have become basic skills in modern education and are now considered to be as important as reading and writing (Supreme Education Council, 2004). The public is aware that the Independent Schools have placed at the center of education students acquiring the skills they need to build a secure future and lead happy and productive lives.

With that in mind, this study examines how the teaching of critical thinking occurs in Qatari Independent School social studies classrooms from the teachers' perspectives. The paper examines how Qatari Independent school teachers understand critical thinking by identifying how teachers define and teach critical thinking, where in the curriculum does critical thinking flourish, and the challenges and limitations teachers face when teaching critical thinking from the perspectives of social studies teachers in preparatory and secondary Qatari Independent Schools.

In what follows, we investigate how critical thinking is currently being taught in Qatari Independent Preparatory (7-9) and Secondary (10-12) Schools from the perspectives of social studies teachers. Our discussion centers on how critical thinking is defined by these teachers, how they are implementing critical thinking in their classrooms and the challenges or limitations they face as they carry out this fundamental aspects of EFNE. Finally, we expand the definition of critical thinking by centering on the weak and strong sense of critical thinking using this understanding to provide recommendations for the teaching of critical thinking.

\section{Teaching Students to Critically Think}

There are many reasons why critical thinking should be taught to students. A main purpose for teaching critical thinking is to improve the thinking skills of students and better prepare them for success in the world. The quality of one's life and career depends on the quality of thought. A contemporary argument is through technology, the amount of information is massive. Students have access to more information than ever before but the challenge remains for students to find, apply, critique and evaluate this knowledge. Thus, students need to

develop and effectively apply critical thinking skills to their academic studies, to the complex problems that they will face, and to the critical choices they will be forced to make as a result of the information explosion and other rapid technological changes" (Oliver \& Utermohlen, p. 1). 


\section{Macrothink}

Lau \& Chan (2011) provide five arguments for the need to develop students' critical thinking skills. These are as follows:

1) Critical thinking is a domain-general thinking skill. All individuals need to be able to engage in critical thinking no mater whatever one chooses to do. Critical thinking skills are not bound to a particular subject area but rather cross discipline boundaries.

2) Critical thinking is vital in our current knowledge economy. The knowledge economy is driven by information and technology that emphasizes not the knowing of knowledge but also the ability to use that knowledge to solve problems.

3) Critical thinking enhances language and presentation skills. Critical thinking can improve the way individuals express their ideas and arguments, their ability to analyze text and critical thinking improves comprehension skills.

4) Critical thinking promotes creativity. Critical thinking lays a key role in developing and evaluating new ideas.5) Critical thinking promotes creativity. Critical thinking plays a key role in developing and evaluating new ideas and develops reflections upon our own values and beliefs. Well-developed critical thinking skills serve as a tool for self-evaluation.Oliver and Utermohlen (1995) argue that students are often passive receptors of information. This argument is relevant to the Qatari context because the reason implementing the teaching of critical thinking in Qatari Independent Schools is to improve upon a educational system that was unchallenging emphasizing rote memorization. Students were constrained from exercising important skills such as questioning and critical thinking (Brewer, et. al., 2007). A major goal of EFNE is to encourage more critical thinking and communications skills that will prepare students for the future and are demanded by employers.

\subsection{Defining Critical Thinking}

The term critical thinking has become such a popular term that people often have quite different understandings of what constitutes critical thinking. EFNE was designed to develop students" "questioning and critical thinking skills" (Brewer, et. al., 2007, p. 103). Therefore, it is important to provide several definitions of critical thinking because the way critical thinking is defined, plays a significant role in determining how critical thinking is taught in the classroom. In essence, the way one understands critical thinking guides their preparation of students to be thinkers.

There are numerous definitions of critical thinking varying in scope. Warnick and Inch (1994), define critical thinking as "involving the ability to explore a problem, question, or situation; integrate all the available information about it; arrive at a solution or hypothesis; and justify one's position" (p. 11). Ennis (1985) argues that "critical thinking is reflective and reasonable thinking that is focused on deciding what to believe or do" (p.45). Scriven and Paul (1987) developed a comprehensive definition for critical thinking for the National Council for Excellence in Critical Thinking: 
Critical thinking is the intellectually disciplined process of actively and skillfully conceptualizing, applying, analyzing, synthesizing, and/or evaluating information gathered from, or generated by, observation, experience, reflection, reasoning, or communication, as a guide to belief and action. In its exemplary form, it is based on universal intellectual values that transcend subject matter divisions: clarity, accuracy, precision, consistency, relevance, sound evidence, good reasons, depth, breadth, and fairness (p. 1)

According to Fischer and Spiker (2000), most definitions for the term critical thinking include terms such as reasoning/logic, judgment, metacognition, reflection questioning and mental processes. Elder and Paul (1994) provide the following definition.

Critical thinking is best understood as the ability of thinkers to take charge of their own thinking. This requires that they develop sound criteria and standards for analyzing and assessing their own thinking and routinely use those criteria and standards to improve its quality (p. 35)

An important aspect of critical thinking is that critical thinkers use these skills appropriately, consciously, involuntary and in a variety of different contexts (Halpern, 1999). Regardless of the instructor or context, critical thinkers have a propensity to raise and explore questions about beliefs, claims, evidence, definitions, conclusions, and actions. More importantly, the common assumption of critical thinking is that these skills can be taught and learned, and when students learn these skills and apply them appropriately they become better thinkers (Halpern, 1999). In what follows, we move the definition of critical thinking further by defining critical in both a strong and weak sense.

\subsection{The Weak and Strong Sense of Critical Thinking}

Paul (1994, 1983) expands the understanding of critical thinking by differentiating between a weak and strong sense of critical thinking. He argues that if thinking is limited to serving the interest of an individual or group and excludes others, it has a weak-sense of critical thinking. He explains that critical thinkers in the weak sense understand the rules of logic to some degree and are capable of engaging in the logical exercise, recognizing false inferences and fallacies, and are able to distinguish bias from fact, opinion, and evidence and can apply acquired knowledge. These are all worthy skills to possess but they are limited in their capacity to examine institutional contexts, social relations and issues of power and interests.

The main concern with the weak sense of critical thinking is that these thinkers are strongly attached to their beliefs that gets in the way of clear reasoning and questioning that could cloud their objectivity. Even if there is a logic applied, these individuals are unaware of how their own background beliefs could shape how they think and have little capacity to challenge their own thinking.

Paul (1984) writes that students typically find it very easy to question just, and only, those beliefs, assumptions and inferences that they have already "rejected" and very difficult, in some cases traumatic, to question those in which they have a personal, egocentric investment (p.3) 
Those who limit critical thinking to the weak sense make little space for conceptual change and weaken their capacity to consider oppositional knowledge. Thus, it raises only questions about their beliefs, assumptions and inferences that have already been rejected. Critical thinking in the weak sense reasons in a very limited way that narrowly defines the issues to one's own frame of reference.

\subsection{The Strong Sense of Critical Thinking}

A strong sense of critical thinking involves individuals deliberately incorporating critical thinking in their lives and requires an open and objective mind to examine knowledge. If critical thinking considers the interests of diverse persons or groups, it would then be considered a strong-sense critical thinking (Paul, 1988). The strong sense critical thinker is similar in some respects to a weak sense critical thinker and different in others. One key aspect of the strong sense of critical thinking is the ability to question one's own perspective and epistemological frames (Paul, 1994). This requires not only an awareness of their assumptions but a willingness to call into question, reflections and possible refutation of these assumptions.

The strong sense of critical thinking moves beyond knowledge application to enable students to develop what Freire (2000) termed "critical consciousness," that is the ability to analyze and critically examine social, political, and economic conditions. This awareness begins the process of questioning and can lead to active struggle against cultural and moral inconsistencies and this could mean changing or adjusting one's mind and position. This type of thinking is intended to provide an awareness of the hidden motivations in our thinking and to unveil the hidden politics within the dominant, as well as all other discourses (Palmquist, n. d.). The strong sense of critical thinking requires an individual to be willing to fairly assess ideas, beliefs and viewpoints even if they have a strong negative reaction to those perspectives.

\subsection{Critical Thinking in the Social Studies}

Educational reform throughout the world promotes critical thinking in which children could transfer that thinking to "real life" contexts. Research in social studies education agrees that critical thinking skills are a necessary part of citizenship education (Beyer, 2006; Cogan, Grossman, \& Liu, 2000). Research also points out that incorporating critical thinking skills into subject matter instruction increases overall achievement in the particular course where critical thinking was integrated (Beyer, 2006).

Research in social studies education points out that critical thinking skills are an essential part of citizenship education and is viewed as the practical link between the social studies curriculum and the implementation of an effective citizenship education program (Beyer, 2006; Cogan, Hartoonian \& Van Scotter, 2000; Thornton, 1994).

Critical thinking has been a major goal of social studies education because social studies is the arena where citizenship consciousness is cultivated. The social studies classroom opens the door to examining social issues and struggles of mankind at the center of a larger context. Subjects such as politics or economics are fertile places to develop students' critical thinking skills. Another reason critical thinking is often embedded in the social studies is that the 
development of critical thinking supports key principles of social studies programs such as inquiry-focused instruction and viewing issues from multiple perspectives.

The majority of teaching of critical thinking in the social studies can be described as a separation of skills from the content. In most social studies classes, the curriculum content is high priority and critical thinking skills are only taught after the content is covered (Case, 2005). Research suggests that when approaching social studies from a critical thinking perspective, it is important to address and provide broad issues of social justice, controversy and debate. Thus by doing less exposition to facts and information and investing more time in developing students' critical thinking skills less content is covered. As critical thinkers, students are cognitively opposed to engaging in critical thinking rather than memorizing facts (Bradley Commission, 1989; Thornton, 1994). Research also shows that integrating critical thinking skills into social studies instruction increases overall achievement on the end of the course assessments (Beyer, 2006).

\section{The Study}

\subsection{Method}

In order to determine how critical thinking is being taught in Qatari Independent Schools social studies classrooms, we developed an open-ended questionnaire used to establish how critical thinking is defined by teachers in Qatar and how they are teaching critical thinking, and the challenges and limitations they face. The research objectives are as follows:

1. To determine how Independent School social studies teachers define critical thinking

2. To examine how teachers teach critical thinking in social studies classrooms

3. To establish what challenges teachers may face as they teach critical thinking in the social studies

4. To offer suggestions based on these findings for the teaching of critical thinking in social studies classrooms in Qatari Independent Schools.

\subsection{Approach to questionnaire and interviews}

A questionnaire was designed to examine respondents' teaching of critical thinking. First, the questionnaire elicited information from teachers regarding their definitions and understanding of what they believe to be the skills that students need to be considered critical thinkers. Then there was a need to discover how these teachers learned to teach critical thinking, how they teach it in the class and what they understand as the best way to instruct students in critical thinking. Finally, the respondents' teaching needed to be placed in context by examining their perspectives regarding the challenges and limitations these particular teachers face. As with any survey instrument, this questionnaire is limited. Therefore follow-up interviews were scheduled and conducted in order to expand on the themes emerging from survey results and to gain clarification and specifics on these themes. 


\subsection{Questionnaire and interview data collection}

A survey questionnaire (see appendix A) was developed consisting of nine open-ended questions to address the above-mentioned objectives. The questionnaire was written in English, we obtained face validity as to how they might be improved by having two of our colleagues examine the questionnaire. The questionnaire was translated into Arabic and judged for the quality of the translations by two bilingual native Arabic speakers with terminal doctoral degrees from US universities.

Twenty-three Qatari Independent Schools were selected for this study. The schools that make up cohorts 1 through 3 were chosen because they have the longest tenure in the educational reform. A Cohort is the group of Independent schools that opened in that particular year. For example, Cohort 1 contained 12 schools that opened in 2004. Cohort 2 schools opened in 2005 and cohort 3 in 2006. There are currently 7 cohorts in the Independent Schools in Qatar. One hundred and twenty surveys were delivered to school and 66 were collected representing a 55 percent return rate. Since all surveys return did not require participants to provide contact information and to allow for further investigate of the questionnaires, participants were asked to provide email addresses if they were willing to participant in an interview. Using this self-selected sample for the interviews was necessary in order to keep confidentiality of the participants. However, there is always self-selection in interview studies because participants must consent to be interviewed (Seidman, 2005). Seventeen teachers provided email addresses and stated that they were willing to participate in a follow-up interview. The sample represents 19 Qatar Independent Schools (representing approximately 14 percent of the Independent School in Qatar); 66 social studies teachers with 16 of those teachers participating in one follow-up interview. This kind of national sample is large to the extent that bias in the sample would be insignificant.

The questionnaires were sent to schools accompanied by a letter describing the purpose of the study and explaining that confidentiality and anonymity would be maintained. The questionnaires were hand delivered by a research assistant to school principal requesting that the surveys were given to each social studies teacher. The research assistant set several dates when the surveys could be retrieved and returned to the school on these dates. Completed questionnaires were collected and translated from Arabic to English. The two bilingual judges have adjusted the language to improve readability such that any change does not alter the content or meaning.

The responses were grouped according to each survey question. Responses to each open-ended question were examined in the context of the research questions. During the analysis, several themes emerged. Themes were then content analyzed and relevant quotes were integrated into various themes in order to support or refute particular findings. The rationale was to provide an accurate account of the teachers' perspectives toward the teaching of critical thinking.

Upon completion of the data analysis, there were several areas that needed to be further discussed with respondents in order to gain in-depth information. Several questions based on the themes were developed to elicit additional information and examples. The themes that need further discussion were how the teachers defined critical thinking; the challenges and 
limitations they faced teaching critical thinking; and the controversial issues they used for debates and discussion in order to teach critical thinking. The following questions were used to elicit additional information from 16 respondents:

What does "critical" mean in critical thinking?

What are the cultural limitations of teaching critical thinking in Independent Schools?

What topics for debates, discussions or analysis did you use when teaching critical thinking?

What controversial issue do you use to develop critical thinking? Point out the controversy. How is it taught? How do you handle the controversy?

What issue(s) would you never present to students to engage in critical thinking?

For example, one of the challenges that emerged from the questionnaire responses was the issue of the use of controversial issues to teach critical thinking. Through interviews, we were able to determine specifically how several teachers utilized controversial issues, the controversy embedded in the particular issue, to what degree of objectivity was presented and how well the teachers presented opposing viewpoints. The semi-structured interviews centered on what respondents think the term "critical" means; possible examples of cultural limitations in further developing controversial issues used to teach critical thinking and how they are taught in the classroom; do these teachers deliberately teach students to ask questions; if they ever challenge students' perspectives, and respondents were asked about their understanding of a strong sense of critical thinking.

\subsection{Sample}

The respondents in this study were all teachers in the Independent Schools. The 66 teachers had a range of experience from one to seven years. Most of the respondents $(n=32)$ fell in the age range between 31-40. Regarding the gender, of the 66 questionnaires returned, females completed 11 and 3 females participated in follow-up interviews.

\subsection{Personal Reflection}

According to Mruck (2000), the reflection of the researcher and the communicative content is often neglected in empirical studies. There are explorative possibilities when the communication between the researcher and respondents and resulting data is placed under a critical self-reflective process. For Nadig (2004) self-reflection is the constant examination of the researcher's thinking and beliefs in regards to the respondents in the research process. This subjectivity is an important methodology tool to gain a deeper understanding of the thinking and motives of the respondents. It is the examination of the researcher's own thinking and experiences that gives insights into the realities of the particular researcher context. In this case, our own experiences working with social studies teachers in workshops, interaction with these teachers in various other contexts and our own research and experiences teaching and living in the culture. Therefore, we engaged in critical self-reflection and dialectical discussions not 
only with each other but several colleagues. These discussions shared the data, respondents' perceptions and often times served to triangulate the data.

\subsection{Limitations of this Study}

As with any study, there are limitations to this investigation that should be considered. Survey research only provides respondents' verbal descriptions of their understandings and thinking on critical thinking and related issues. Respondent responses cannot always be taken as totally accurate descriptions of what the respondents actually do or really think. In addition, open-ended questionnaires often represents, an over simplification of social reality. Knowing that, this research provides a snapshot of the faculty members' perceptions. Finally, anytime translation is involved in research, there is always a concern regarding what may or may not be lost in the translation or how translated questionnaires may shape respondents' responses. In spite of these limitations, this research provides valuable insight into how social studies teachers in Qatar Independent Schools understand and teach critical thinking, the challenges they face and their professional suggestions as to the best way to approach the teaching of critical thinking.

\section{Findings}

The primary focus in the findings section is to provide a descriptive overview of how critical thinking is understood and being taught in the Qatari Independent preparatory and secondary school social studies classrooms. Each particular finding is presented and discussed in detail supported by relevant respondent quotes and then discussed based on information gained during the follow-up interviews.

\subsection{Defining Critical Thinking and Skills Needed for Critical Thinking}

The large majority of the teachers understood critical thinking as the process of making judgments, evaluate or analyze situations and thinking that shows the "positives and negatives" and reaching a conclusion or a solution to a problem. Teachers believed that rational, "constructive" thinking, problem solving, or making a decision seemed to be dominant features of the respondents understanding of critical thinking. Some of the responses are listed below:

Is the ability of a person to recall a topic and realize its positives and negatives?

It is the ability of a well-balanced individual to contribute to problem solving and his social problems

It is the ability to evaluate a topic in a constructive manner

The above quote illustrate some of the components that make up critical thinking for these teachers. However four teachers advanced the definition of critical thinking further by indicating that there was a moral component to critical thinking that required the thinker to determine "right and wrong." Several respondents' quotes illustrate this component:

Thinking and the differentiation between right from wrong 
The thinking that enables students to differentiate rights from wrongs and make judgments

The respondents focused on the moral aspects of critical thinking making informed decisions considering issues centering on morality.

Among the respondents were those whose responses indicated some formal instruction on critical thinking because of their use of the "traditional" language of critical thinking. Several utilized such language such words as analyzing, criticizing, evaluating, creativity and considering all viewpoints.

Finally, respondents identified the skills essential for students to possess in order to be considered critical thinkers. Responses ranged from thinking; to understanding; to exploration and discovery; to intellectual speaking. Some of the more consistent responses include: asking or asking "deep" questions (22 percent); analysis skills (15 percent); application (11 percent); criticism ( 9 percent); and deduction (7 percent). Others included criticizing and convincing others; realizing the credibility of information; observation; objectivity; and classification

Based on these responses, several follow-up interviews were conducted to probe questionnaire responses. One concern was how these respondents understood the term "critical." One issue that needs to be pointed out is when the term critical is translated from English to Arabic the term means "criticism." This is important because of the meaning of critical as in critical thinking is to criticize the issue constructively presenting negative and positive sides. It is constructive criticism. Arabic has negative connotations and in certain contexts the cynical sense of the word transpires in unintended meaning.

Follow up interviews supported much of what was expressed in survey responses regarding respondents' understanding of critical thinking. Several respondents stated that critical thinking, "shows the pros and cons;" "focuses on what is believed by an individual from the negatives or positives;" "criticizing information each according to his opinion;" "criticizing something;" and finally it is "to make the students think."

\subsection{Learning How to Teach Critical Thinking}

When addressing where these teachers learned to teach critical thinking in their classroom, 46 percent of the respondents responded that they did not have any "formal" teaching as to how to utilize critical thinking in the social studies. Instructional hours refer to workshops or courses specifically designed for the teaching of critical thinking.

Table 1: Hours of Instruction in Critical Thinking

\begin{tabular}{l|l|l}
\hline \multicolumn{1}{c|}{ Number of Respondents } & \multicolumn{1}{|c}{ Instructional Hours } & Percentage of Sample \\
\hline 32 & None & $47 \%$ \\
27 & $1-10$ & $39 \%$ \\
8 & $11-20$ & $12 \%$ \\
0 & $21-30$ & $0 \%$ \\
2 & More than 30 & $2 \%$ \\
\hline
\end{tabular}


Table 1 illustrates the number of hours of instruction in critical thinking received by the respondents.

Responses to an additional survey item, illustrates the various ways that these teachers said that they learned how to engage and teach critical thinking. Several quotes illustrate how they learned to teach critical thinking:

Through years of teaching experience

Workshops and books

Through looking at some books and the workshops organized by a foreign support team at the school

Through the Internet and training sessions

A large number of respondents stated that they learned to think critically through personal life experiences, reading, many years teaching and the use of professional standards. Few stated that they learned how to critically think or how to teach critical thinking.

Regarding the follow-up interviews, teachers indicated that they lacked a specific strategy or way of teaching critical thinking. The following quotes illustrate this point.

There are no limitations, but there is also no strategy. The Supreme Education Council offers no strategy in teaching critical thinking. No resources were given. So, we teach that spontaneously.

Throughout our lessons we use critical thinking, but we have not studied it.

It seems that there is an awareness of the need and ways to teach critical thinking but this might happen involuntary rather than in a well thought out deliberate manner.

\subsection{Current and Best Approach to Teaching of Critical Thinking}

Two important items on the questionnaire requires respondents to reflect upon their own teaching and to determine if and how they teach critical thinking to their students and to stated what they thought was the "best" way to teach critical thinking. When it comes to the teaching strategies that social studies teachers use in the Independent School classrooms, 63 percent of the respondents stated that they use questions, problem solving and discussion to develop critical thinking in students. 
Table 2: Strategies to Teach Critical Thinking

\begin{tabular}{l|c|l|c}
\hline \multicolumn{1}{c|}{$\begin{array}{c}\text { Teaching Strategies } \\
\text { Used }\end{array}$} & $\begin{array}{c}\text { Number of } \\
\text { Responses }\end{array}$ & \multicolumn{1}{|c}{$\begin{array}{c}\text { Best Strategies to Teach Critical } \\
\text { Thinking }\end{array}$} & $\begin{array}{c}\text { Number } \\
\text { of } \\
\text { Responses }\end{array}$ \\
\hline Asking Questions & 22 & Discussion & 13 \\
Problem Solving & 12 & Debates & 11 \\
Discussion & 9 & Solving Problems & 8 \\
Brainstorming & 9 & Curriculum changes: Redo current & 6 \\
& & curriculum or add a course in critical & \\
Internet, PowerPoint, & 7 & Collaborative Learning & 5 \\
worksheets, pictures & & Presenting Different perspectives & 5 \\
Evaluation & 4 & Research & 3 \\
Examining sources & 3 & Brainstorming & 2 \\
Movies & 3 & Analyzing topics & 2 \\
Organizing Information & 3 & Discovery and Deduction & 4 \\
Research & 1 & Asking Questions & 1 \\
\hline
\end{tabular}

Table 2 illustrates what respondents thought was the best strategy to teaching critical thinking and the strategies they most often used in their classrooms.

Participants' responses indicate that asking questions is the strategy most often used by teachers to develop critical thinking in students. However, only one respondent stated that asking questions is the best approach to teaching critical thinking. Discussion was high for both strategies used and best perceived teaching strategy (see table 2) but respondents never disclosed how discussions are conducted or used to teach critical thinking. In addition, most teachers asking questions was vital in the development of critical thinking yet only one respondent listed Bloom's work as an important teaching strategy to develop students' critical thinking skills. When respondents were asked about teaching students to ask questions, the following illustrate the teachers' perspectives.

As teachers we did not know that this type of thinking has steps. By next year we will have plans.

It is the fundamentals of teaching. Among teaching strategies is how to ask questions ... when I taught a lesson about Australia. I presented pictures of it and through these pictures I asked what you know (K) about Australia, what do you want to know (W) and at last, what did you learn (L)

The response shows the lack of information and knowledge about teaching critical thinking this teacher possesses. Also, the strategy of teaching Australia using the K-W-L model is a good way to develop questioning skills but unless taught, students will use the K-W-L at the lower level of thinking such as memory and comprehension, failing to raise the questions and issue that critical thinking demands. The K-W-L is a teaching model designed to help students learn 
from text in any content area. By asking the question: What I Know, What I Want to Learn, What I Learned.

\subsection{Challenges to Teaching Critical Thinking*}

Regarding the teaching of critical thinking, social studies teachers face several challenges that can be reduced to two areas: time and students. First, 20 percent of all teachers argue that there is limited time large curriculum content that must be covered and if critical thinking is taught, they would not be able to finish the curriculum required by the school. There are too many duties for teachers and the planning and teaching of critical thinking requires too much time. The following quote illustrate this view:

There is not enough time to present critical thinking in the right way. There are too many duties already given to the teacher.

Second, 52 percent of the teachers point out that there are two aspects of students as a challenge to the teaching and development of critical thinking. Of the 52 percent, 68 percent ( 24 teachers) focused on the students' lack of abilities to engage in critical thinking. The following quotes illustrate this point:

There is difficulty of teaching critical thinking to some students because they face academic problems that don't allow them to grasp this idea

Some students with low level thinking skills such as memorizing, recalling and understanding will have difficulty and progress but slowly

Students do not want to think or participate. They express shallow ideas

The thinking is that only a particular group of students can engage in critical thinking because their "academic abilities" allows for this type of education. In addition, students' lack of motivation or unresponsiveness is a challenge for teachers. Of the 52 percent of respondents who centered on students as a challenge, 48 percent (17 teachers) stated that students were nonresponsive to the teaching of critical thinking and lack motivation to engage in this type of learning.

One concern for the researchers was that it could be possible that students find themselves unmotivated or unresponsive because they lack the critical thinking skills needed to fully participate in the lessons and assignments. During the follow-up interviews, teachers were asked if they actually taught students how to critically think. The following response indicates some insight into how these teachers address critical thinking.

Yes, through standards and strategies such as the six hats [the de Bono hats system better known as six hates is a teaching strategy for group discussion and individual thinking. The "hats" are as follows: Information: Emotions, Bad points judgment, Good points judgment, Creativity and Thinking] I use the six hats strategy teaching them that. I study the personalities of my students one is pessimistic and another is optimistic. Based on these personalities they are assigned worksheets or colored hats. Example the one who is given the yellow hat is the one 
with the critical view. While, the white hat student is the optimistic. Topics like tourism interest students and encourage them for discussion.

The above quote is one of the most clearly articulated methods any teacher described for teaching critical thinking. This individual received a PD program that taught this method and he seems to understand how to use this particular method to provide students with opportunities to develop their critical thinking skills.

\subsection{Limitations}

The majority of respondents defined limitations as what they could or could not talk about in the classroom. Fifty-six percent of the respondents reported that there are no limitations or topics that could not be critically thinking about in their school. The following two quotes illustrate respondents' thinking on limitations.

There are no limits to knowledge. Therefore, I encourage my students to critical think and question ... I criticize if it is constructive criticism.

There can be sensitive subjects on the grounds that if it only show only the negatives.

I do not criticize. I correct and I express respect to the student's opinion and how it is not complete

Notice that these comments express that the way one knows the limitations of knowledge is if the criticism of a "sensitive topic" is negative. Accordingly, teachers can address any topic as long as the discussion is positive or if the students" viewpoint is "correct."

Several additional comments surfaced that are worth mentioning. First, several respondents suggested that teachers lack the understanding of critical thinking which clearly is a limitation to the teaching of critical thinking. Also, some argued that although teachers may know about critical thinking, they lack the knowledge and resources to apply this to the classroom. They suggest that workshops be provided that give these skills to teachers so they could apply these in their classrooms.

\subsection{Controversial Topics}

Regarding the use of "controversial issues," when teachers were asked if they ever raised any controversial topics in order to teach students critical thinking, 97 percent of the teachers stated that they used various controversies with only three respondents stating they did not. The topics considered controversial vary among the respondents. Teachers listed the following controversial issues they use in the classroom: the current revolution in the Arab world in Egypt, Tunisia and Libya; the Palestinian issue; the occupation of Iraq; human rights; the Israeli occupation; the problem of Gaza; Islam and the West; the Arab Palestinian conflict; freedom of opinion and expression in Qatar; Israeli terrorism; the topic of expats, low-waged immigrant laborers or house maids; the impact of colonialization on the Arab world; American dominance and control over countries of the Arab world.

Although these teachers stated that they have raised controversial issues in their classes, the simple listing of a topic does not provide the needed information as to how they handle the 
controversy and this does not encourage the strong sense of critical thinking. Follow-up interviews centered on how the controversy was defined, the viewpoints presented, how the controversy was taught and the handling of the controversial issue. The data gained from interviews indicates that some of these teachers tried to present multiple viewpoints on controversial topics approaching the "line" that divides the weak and strong sense of critical thinking but never "making the leap."

The follow-up interviews provide additional insight. The following quotes hints as to how these teachers address controversy in the classroom.

Through debate ... The subject of the debate is terrorism ... many of the views about terrorism and the difference between them and the Jihad and Islam's position on terrorism.

Expat labor is it positive or negative.

The concept of "legitimate terrorism" opens opportunities for discussion and dialogue.

When asked about areas that should not be discussed, the follow-up interviews indicated that several issues are placed beyond criticism. Several respondents stated that the Quran, religion and some political matters are off limits for teachers and students to engage in critical thinking

The follow-up interviews address an important concern. That is, how teachers addressed students' viewpoints. When asked if they challenged their students perspectives and viewpoints, 55 percent of the teachers (9 teachers) participating in an interview that did challenge students "because there were different opinions," "students must support their viewpoints," and "this is part of critical thinking, isn't it?" However other teachers indicated that they often did not challenge students' views. The following quote illustrates one respondent's perspective.

I don't criticize my students, but I tend to try to prolong the discussion and dialogue. I open the conversation in a normal way and encourage them to dialogue. It is not important if they have positive or negative views of an issue. The important thing is that they start discussing these issues

This quote seems to indicate that dialogue with others is the primary purpose of discussion and critical thinking is secondary.

\section{Discussion and Reflections}

These findings prove insightful for the current Qatari educational reform because they provide insight into how teachers in the Independent Schools in Qatar define and teach critical thinking based on their understanding of critical thinking and EFNE's requirement to develop students' "questioning and critical thinking skills" (Brewer, et. al., 2007, p. 103). Viewed from a comprehensive definition of critical thinking that includes the weak and strong sense of critical thinking and coupled with personal reflection, these findings raise a variety of important issues and concerns regarding teaching critical thinking in the Independent Schools, social studies classrooms that need further discussion. To begin with, it is clear that respondents' definitions and understandings of critical thinking are limited to the weak sense. Although at times there 
are hints of strong sense (issues of morality and addressing controversial topics), these are limited and are never fully described to determine if the strong sense is taught to students.

There is an alarmingly 46 percent of teachers reporting that they did not receive any formal instruction regarding the teaching of critical thinking in the social studies. Because of the emphasis place on critical thinking by the educational reform, many respondents stated that they learned critical thinking through experience and their own reading. A large number of respondents stated that they learned to think critically through personal life experiences, reading, their own teaching and the use of professional standards. It seems that there is a lack of reflection on their own critical thinking and also a lack of a deliberate teaching strategy. One teacher described his use of the "six hats" strategy that illustrates critical thinking and a deliberate teaching strategy but there is little evidence that this moves critical thinking into the strong sense.

The majority of teachers surveyed and interviewed viewed critical thinking as a time consuming process that requires a reduction of curriculum content to be covered and fail to see the teaching of critical thinking as a framework that could guide instructional strategies. This finding is reinforced by the fact (as mentioned above) that most teachers did not have any formal instruction regarding the teaching of critical thinking. Coupled with teachers' low expectations of students and a lack of skills required to integrate critical thinking into the curriculum, one can easily see how critical thinking becomes secondary to the covering of curriculum and learning outcomes. However, when critical thinking is used as the framework around which instruction is designed, the students are more engaged and do more than just listen (Duron, Limbach \& Waugh, 2004). Teaching critical thinking does not overshadow the importance of content but rather it makes the content more exciting to negotiate and analyze. Thus, by framing teaching within critical thinking, the content is more likely to be internalized by students.

A close examination of the findings indicates that the teachers lack a solid theoretical background regarding not only the complexities of critical thinking teaching strategies but also the pedagogical theory that informs their practice. Teachers say questioning is important but never mention what guide their development and questioning patterns to develop critical thinking. One respondent mentions Bloom's while only one respondent describes the use of the six-hat strategy. A respondent's comment illustrate this strategy: "There is no strategy and I have not read sources on how to teach my students critical thinking. I teach them critical thinking through open discussions that develop critical thinking." Although these teachers may be wonderful at asking higher level thinking questions and sparking critical thinking in students, our concern is illuminated by the latter quote is that teacher use a variety of strategies to teach critical thinking not knowing if they really work in the classroom, hoping that in the midst of the discussion, critical thinking will develop on its own. We are concerned that some of these teachers are merely technicians: "uncritical, "objective," and "efficient" distributors of information" who neglect the more critical aspects of culture and schooling (Giroux \& McLaren 1996, p. 304). Technicians are unaware or unable to articulate their educational philosophy and the underlying epistemological underpinnings that serve as the foundation of their teaching. In this case, technicians seldom critically interrogate how 
they define and understand critical thinking, how student learn to critically think, the purpose of developing critical thinking and the pedagogical theories that inform their classroom practice.

The strong sense of critical thinking is another aspect of these findings that needs to be more closely examined. There is a real concern about how controversial issues are raised in the classroom and how these teachers define the limitations when teaching critical thinking. We have argued elsewhere (Romanowski \& Nasser, in press) that there are cultural limitations regarding the topics that could be addressed in public dialogue. Although many teachers stated there are no limitations, we find this troublesome to some degree. From our own experiences, we would argue that the respondents who stated that the religious and some political matters were off limits for teachers and students to engage in critical thinking and provide a very accurate assessment of what can and cannot be questioned and placed in the context of critical thinking. Still fifty-six percent of the respondents reported that there are no limitations or topics that could not be critically thought through about in their school and 97 percent use controversial topics to teach critical thinking.

The key element here is how one defines critical thinking. As previously mentioned, respondents often discuss critical thinking in terms of negative and positive criticism. It seems as though as long as the discussion is "positive," then there are no limitations when teaching critical thinking. As soon as sensitive topics undergo critical interrogation (what teachers would say is addressing the negatives), limitations begin to surface. Therefore, although topics could be considered controversial, the perspectives that are allowed to evolve in the discussion is what makes knowledge controversial. For example, controversial issues related to the government might be addressed as long as negative criticism is avoided, thus removing any real controversy or at least not formally addressing the concern. This is similar to saying there is a big elephant in the room. Everyone knows it, the "elephant" is there, it smells, makes noise but no one talks or mentions the "elephant." The same goes for controversy. If this is the case, then the weak sense of critical thinking fails to challenge the status quo or students' and teachers' own perspectives. There cannot be any "negatives" allowed in the discussion. One respondent stated; "I don't avoid any topics because that goes against the concept of critical thinking." This might be the case but the pedagogical issue in this context related to the teaching of critical thinking centers on how the controversy is framed, the perspectives that are legitimize, delegitimize and omitted, and if the goal of instruction is the development of a strong sense of critical thinking or is the lesson objectives limited to the weak sense of critical thinking.

We would also signify the possibility there could be a lack of "objectivity" when teaching these controversial issues or that these issues are taught in a culturally accepted way or where one particular discourse dominates the defining of the controversy and the discussion. The teachers' language when describing the controversy illustrates their perspectives. For example, think about how the following terms would be viewed from a western perspective (particular American); the occupation of Iraq; the Israeli occupation; Israeli terrorism; the impact of colonialization on the Arab world; American dominance and control over countries of the Arab world; and the Gaza war and the opinion of Hamas with or against. Certainly the bias in the 
viewpoints put forth in these short descriptions is evident, (a bias would also be evident if western teachers described these events) our concern is for the strong sense of critical thinking to develop multiple perspectives.

To summarize, the respondents in this study have a limited definitions of critical thinking and lack any formal instruction that fully defines the term or provides effective pedagogical strategies for students to develop their critical thinking skills. The respondents use various strategies but this seems to be without a theoretical understanding regarding the use of the particular strategy. At times, the strategies (i.e. discussions) might not be fully effective to develop critical thinking and teachers would need further instruction to perfect the strategy in order to get the most benefit. Based on these findings, there are several recommendations that can put forth not as simple solutions but rather as beginning steps to develop educational philosophies in teachers that enable them to integrate critical thinking throughout the curriculum.

\section{Recommendations}

Critical thinking requires that learners interpret life in all its complexities. However, not all countries or educational systems teach or have taught students to engage in critical thinking, especially in the strong sense. Brookfield (1995) points out that "across the world people live lives in which the possibility for critical reflection remains unrealized, either through political oppression, apathy, poverty or educational neglect" (p. 4). The key about developing critical thinking could be found in Horowitz's quote: "You can't get a good education if they're only telling you half the story." We have written elsewhere the limitations that can be placed on critical thinking in Qatar regarding telling the complete story (Romanowski \& Nasser, in press) and this is vital to understand the current and future possibilities for critical thinking in the Qatari Independent Schools.

The concern for these teachers regarding teaching students a strong sense of critical thinking is that the SEC has defined what critical thinking is and the definition and at times, can eliminate or hamper the development of the strong sense of critical thinking. The SEC recently "asked all private schools to ensure that any information that they give to students about Qatar is authentic and they don't teach anything that goes against the country's culture, religion and traditions" (Peninsula, 2011). Although this is directive is for private schools in Qatar, it can easily be inferred that the same policy is in place for Independent Schools. More importantly, this directive is enforced; "any school found to be violating this directive would face legal action" (Peninsula, 2011). In addition, "Every school has been instructed to set up a special committee to scrutinize all its books and study material to ensure that they conform to the SEC guidelines" (Peninsula, 2011). This climate makes it difficult but not impossible for teachers to move critical thinking from the weak sense to the strong sense. Nevertheless, let us provide several suggestions for improving critical thinking in Independent Schools.

First, teachers must develop a deep and comprehensive understanding of critical thinking and the pedagogical skills needed to provide sound opportunities for students to and engage in critical thinking. This requires teachers to fully grasp both the strong and weak sense of critical thinking and begin an educational philosophy that enables them to apply both senses of critical 
thinking to their particular context. There is a need for formal instruction that provides teachers with both theory and practical application. This instruction must be based on the idea that critical thinking is not just a goal for teaching social studies but rather a method to teach social studies. Thus, social studies teachers do not just add critical thinking to the already overloaded curriculum but rather critical thinking is integrated within the existing curriculum. More importantly, from our experiences as professors, teachers in this context seem to value answers and there is little value for questions. Often learning is viewed as providing answers rather than a process of negotiating meaning and this perspective would need to be challenged.

The teaching of controversial issues, discussing emotive issues, comparing and contrasting information, justifying opinions and drawing inferences, explaining their views, asking relevant questions, generating new ideas and judging the value of their own and others' work or ideas, develops students critical thinking skills (Oxfam, 2006). Moreover, without controversy (or at least, disagreement), teaching students to think critically is extremely difficult, if not impossible. As previously discussed in this particular context, there are some limitations regarding the topics and perspectives that can be presented and examined but the skills of a strong sense of critically thinking can be developed and practiced on appropriate issues that are acceptable within the independent school context. Thus, bringing controversial subjects into the classroom, addressing differences in the social studies classroom provides ample opportunities to develop both the weak and strong sense of critical thinking and these are used quite often, teachers need to consider several questions regarding the teaching of controversial subjects. These include but are not limited to:

1. What is your role in dealing with controversial issues in the classroom and the accompanying challenges?

2. What makes an issue controversial and why am I using it? [The reason behind materials election and use is vital and teachers must provide a well thought out professional response that justifies the decision]

3. What are the competing values and interests?

4. How can I develop a critical consciousness in students via the controversial issue?

[The ability to analyze and critically examine social, political, and economic oppression and to take action against the oppressive elements of society (Freire, 2000)]

5. How can you get students to better understand their limited experiences and perspectives and come to new understandings?

6. How can I make controversies an object of critical examination?

7. How can I make sure that there is an ideological balanced presented for the issue?

8. Which teaching strategy(s) do you think is the best way to handle controversy in the classroom?

9. Is the information authentic and accurate and does it go against the country's culture, religion and traditions? 
10. Are the materials use to promote critical thinking in the strong sense in conformity with Islamic values and principles as well as the culture, tradition and heritage of the country?

We would argue that in spite of the limitations place on critical thinking in the independent school context, using these questions as guidelines for the selection of topics and issues as materials to develop a strong sense of critical thinking will allow teachers to provide opportunities for students to engage in both the weak and strong sense of critical thinking within the independent schools.

Social studies teachers, need to provide opportunities for students to develop an understanding that knowledge is never value-free and objective but the knowledge presented only represents one of the many possible perspectives. Loewen (1995) suggests that social studies teachers teach in a more critical manner by putting five questions to work:

1. Why was a particular event written about?

2. Whose viewpoint is presented, whose is omitted and whose interests are served?

3. Is the account believable?

4. Is the account backed up by other sources?

These questions will provide opportunities for students to become conscious of the many ways of looking at the world and avoid being are passive victims of imposed meanings.

In addition, it is vital for teachers to understand that there are multiple perspectives that can be presented within the social studies content and that determining what perspectives students should be exposed to, relies upon one's educational philosophy. Teachers need to engage in reflection necessary to uncover the values embedded in their pedagogical and their view of content knowledge. For example, this can be accomplished through Schwab's (1978) "polyfocal conspectus." This is a system of critical reflection of subject matter through multiple perspectives that exposes and "lifts out" the values and ideologies embedded in the varying viewpoints. Each perspective is "studied, interpreted, discussed, and debated" (p. 346). The value-laden perspectives are then compared to give teachers a sense of the many possible interpretations and the strength and weaknesses of their own perspective.

In closing, critical thinking is not an educational tool that you either teach or do not teach. Instead it is a toolbox of useful skills, strategies and dispositions that develop critical thinking. The issue is how much critical thinking that a teacher teaches in a classroom all depends on how they see the development of critical thinking in relation to all the other important objectives and goals.

\section{Acknowledgement}

This study was funded by a Qatar University Internal Grant \# QUEST-CED-ESD-10/11-8 


\section{References}

Banks, J. A. (1998). The lives and values of researchers: Implications for educating citizens in a multicultural society. Educational Researcher, 27(7), pp. 4-17.

Beyer, B. K. (2006). Put your mind to it. Virginia Journal of Education, 100 (2), pp. 6-10.

Bradley Commission on History in Schools. (1989). Building a History Curriculum Guidelines for Teaching History in Schools. History Teacher, 23 (1), pp. 7-35. http://dx.doi.org/10.2307/494598

Brewer, D. J., Augustine, C. H., Zellman, G. L., Ryan, G. W., Goldman, C. A., Stasz, C., \& Constant, L. (2007). Education for a New Era: Design and Implementation of K-12 Education Reform in Qatar. Rand Corp: Santa Monica, CA. Retrieved from: http://www.rand.org/pubs/monographs/MG548/ (July 3, 2011)

Brookfield, S. D. (1995) Postscript: An agenda for research and policy. In A Tuinjman (ed.) International encyclopedia of education. Oxford: Pergamon Press.

Case, R. (2005). Moving Critical Thinking to the Main Stage. Education Canada, 45(2), pp. 45-49.

Cogan, J.J., Grossman, D., \& Liu, M.H. (2000). Citizenship: The Democratic Imagination. In a Global/Local Context. Social Education, (11), pp. 48-53.

Duron, R., Limbach, B., \& Waugh, W. (2004). Critical thinking framework for any discipline. International Journal of Learning and Teaching in Higher Education, 17(2), pp. 160-166.

Elder, L., \& Paul, R. (1994). Critical thinking: Why we must transform our teaching. Journal of Developmental Education, 18(1), pp. 34-35.

Ennis, R. H. (1985). A Logical Basis for Measuring Critical Thinking Skills. Educational Leadership, 43, pp. 45-48.

Fischer, S. C., \& Spiker, V. A. (2000). A framework for critical thinking research and training. (Report Prepared for the U. S. Army Research Institute).

Freire, P. (2000). Pedagogy of the oppressed, $30^{\text {th }}$ anniversary edition. New York: Continuum Publishing Company.

Giroux, H. A., and McLaren, P. (1996). Teacher Education and the Politics of Engagement: The Case for Democratic Schooling. In Breaking Free: The Transformative Power of Critical Pedagogy, edited by P. Leistyna, A. Woodrum and S. A. Sherblom, pp. 301-331. Cambridge, MA: Harvard Educational Review.

Halpern, D. F. (1999). Teaching for critical thinking: Helping college students develop the skills and dispositions of a critical thinker. New Directions for Teaching and Learning, 80, pp. 69-74. http://dx.doi.org/10.1002/tl.8005

Hartoonian, H.M., \& Van Scotter, R. (2000). The real business of America. Ethics and Education, 20, pp. 223-254. 


\section{Al Macrothink}

International Journal of Education

ISSN 1948-5476

2012, Vol. 4, No. 1

Lau, J., \& Chan, J. (2011). About critical thinking: What is critical thinking and why is it important? Retrieved from: http://philosophy.hku.hk/think/critical/ct.php (June 22, 2011).

Loewen, J. W. (1995). Lies my teacher told me: Everything your American history textbook got wrong. New York: The New Press.

MENA Development Report (2008). The road not traveled education reform in the Middle East and North Africa. Washington D.C.: The International Bank for Reconstruction and Development / The World Bank.

Mruck, K. (2000). Qualitative Research Networking: FQS as an Example. In Forum Qualitative Sozialforschung / Forum: Qualitative Social Research [Online Journal], 1(3). Available: http://qualitative-research.net/fqs-texte/3-00/3-00mruck-e.htm (May, 22, 2001).

Nadig, M. (2004). Transculturality in process. Theoretical and methodological aspects drawn from cultural studies and psychoanalysis. In: Sandkühler, Hans Jörg; Lim, Hong-Bin (eds.) Transculturality, Epistemology, Ethics, and Politics. Frankfurt am Main: Lang, pp. 9-21.

Oliver, H., \& Utermohlen, R. (1995). An innovative teaching strategy: Using critical thinking to give students a guide to the future. (Eric Document Reproduction Services No. 389 702)

Oxfam (2006). Global citizenship guides: Teaching controversial issues. Oxfam Development Education Program: Oxford, UK.

Paul, R. (1994). Teaching critical thinking in the strong sense. Re-Thinking Reason: New Perspectives in Critical Thinking, In Kerry S. Walters, ed. (Albany: SUNY Press), pp. 181-198.

Paul, R. (1983). An agenda item for the informal logic / critical thinking movement. Informal Logic Newsletter, 5 (2), pp. 23.

Peninsula, (September 12, 2004). SEC invites school operators to join Education for a New Era scheme. Retrieved from: http://archive.thepeninsulaqatar.com/component/content/article/349-qatar-newsarchive/34497 .html (April, 20, 2011).

Peninsula, (September 14, 2011). Respect Qatari culture, SEC tells schools. Available: http://www.thepeninsulaqatar.com/qatar/165215-respect-qatari-culture-sec-tells-schools.html (October 21, 2011).

Romanowski, M. H., \& Nasser, R. (In press). Critical Thinking and Qatar's Education For a New Era: Negotiating Possibilities. International Journal of Critical Pedagogy.

Schwab, J. (1978). The practical: Arts of eclectic. In I. Westbury \& N. Wilkof (eds), Science, curriculum and liberal education, pp. 322-364. Chicago: University of Chicago Press.

Scriven, M., \& Paul, R. (1987). Critical thinking as defined by the national council for excellence in critical thinking. Retrieved from: http://www.criticalthinking.org/aboutCT/define_critical_thinking.cfm (March, 10, 2011). 
Seidman, I. (2005). Interviewing as qualitative research: a guide for researchers in education $\left(3^{\text {rd }}\right.$ ed.). New York: Teachers College Press.

Supreme Education Council (2004). Heir Apparent Highlights "Education for a New Era". Retrieved from: http://www.english.education.gov.qa/content/resources/detail/853 (April 20, 2011).

Thornton, S.J. (1994). The social studies near century's end. Review of Research in Education, 20, pp. 223-254. http://dx.doi.org/10.3102/0091732X020001223

Warnick, B., \& Inch, E. S. (1994). Critical thinking and communication (2nd ed.). New York: Macmillan.

\section{Appendix}

Appendix 1. Critical Thinking Questionnaire

Thank you for your time and your willingness to complete this survey. Please respond to the following questions as specifically as possible. Also, attach any evidence that would support your responses.

Your nationality (tick $\sqrt{ }$ the box as appropriate to you)

\begin{tabular}{|c|c|}
\hline Qatari & \\
\hline Non-Qatari (Arab) & \\
\hline Other (list) & \\
\hline
\end{tabular}

1. Age (tick $\sqrt{ }$ in the box as appropriate to you)

\begin{tabular}{|l|l|}
\hline $26-30$ & \\
\hline $31-40$ & \\
\hline $41-50$ & \\
\hline $51-60$ & \\
\hline
\end{tabular}

2. Gender (tick $\sqrt{ }$ in the box as appropriate to you)

Male $\quad$ Female $\quad \square$

3. Years teaching experience in Independent Schools (write the number)

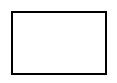

4. How much training have you had regarding the teaching of critical thinking? Please list how many hour of specific training you received 
1. How would you define Critical Thinking?

a. What skills do students have if they are critical thinkers?

2. How do you teach Critical Thinking in your classes? What specific techniques do you utilize for teaching Critical Thinking? Please provide specific examples. If possible, attach any materials or lesson plans.

3. What are the challenges you face when teaching critical thinking?

4. Are there limitations or topics that cannot be critically thinking about in your Independent School? Provide examples.

5. Do you think students are taught Critical Thinking well enough? If so, why? If not, why not?

6. What is the best way to teach critical thinking in Qatari Independent schools?

7. Do you ever raise any controversial topics in order to teach students critical thinking? Please give examples

8. Where did you learn to teach critical thinking in your classroom?

9. Additional Comments or concerns.

\section{Copyright Disclaimer}

Copyright reserved by the author(s).

This article is an open-access article distributed under the terms and conditions of the Creative Commons Attribution license (http://creativecommons.org/licenses/by/3.0/). 